\title{
Identifikasi Potensi Batuan Induk pada Formasi Santul di Sub-Cekungan Tarakan, Kalimantan Utara
}

\author{
Desi Indah Purnama ${ }^{a^{*}}$, Yoga Satria Putra ${ }^{a}$ Muhardia $^{\mathrm{a}}$, Nur Hayati ${ }^{\mathrm{b}}$, Afriadhi Triwerdhana ${ }^{\mathrm{b}}$ \\ aProgram Studi Geofisika Universitas Tanjungpura, Jalan Prof. Dr. H. Hadari Nawawi Pontianak \\ bEksplorasi PT. Pertamina EP, Jalan Prof. Dr. Satrio Jakarta \\ *Email : desiindahpurnama@gmail.com
}

\begin{abstract}
Abstrak
Penelitian ini dilakukan pada sampel batuan di Formasi Santul dari lima sumur pengeboran yaitu sumur M-1, M-2, M-3, M-4, dan M-5. Identifikasi kuantitas dan kualitas, tipe dan kematangan material organik berdasarkan analisis nilai TOC, Rock Eval Pyrolisis (REP), Reflektansi Vitrinit (Ro\%). Hasil penelitian menunjukkan bahwa Formasi Santul di lokasi penelitian memiliki kualitas cukup hingga istimewa (fairexcellent) sebagai batuan induk dengan nilai TOC 0.99 hingga $10.81 \%$. Kerogen didominasi kerogen tipe III yang berpotensi menghasilkan hidrokarbon dalam bentuk gas dan kerogen tipe II/III yang berpotensi menghasilkan hidrokarbon dalam bentuk campuran antara minyak dan gas. Hasil penelitian juga menunjukkan bahwa tingkat kematangan batuan induk Formasi Santul yaitu belum mencapai tingkat matang hingga matang dengan nilai 0.27 hingga $0.71 \%$.
\end{abstract}

Kata Kunci : Batuan Induk, Geokimia, Reflektansi Vitrinit, Rock Eval Pyrolysis, Total Organic Carbon

\section{Latar Belakang}

Eksplorasi minyak dan gas bumi di Cekungan Tarakan telah dimulai pada abad 19[4]. Seiring berjalannya waktu kebutuhan eksplorasi semakin meningkat untuk memenuhi kebutuhan sumber energi. Untuk memenuhi kebutuhan sumber energi diperlukan metode atau teknik eksplorasi yang dikembangkan untuk mengoptimalkan penemuan dari hasil eksplorasi sebelumnya ataupun menemukan cadangan sumber energi yang baru sehingga tercapainya kebutuhan sumber energi.

Sampel batuan dari sebuah sumur pengeboran merupakan parameter utama untuk analisis potensi batuan induk dalam sebuah eksplorasi minyak dan gas bumi. Analisis potensi batuan induk sangat diperlukan untuk memenuhi kebutuhan sumber energi. Penelitian terkait hidrokarbon dapat dilakukan dengan mengidentifikasi potensi pada suatu batuan induk, yaitu batuan yang mempunyai kemampuan untuk memproduksi hidrokarbon dalam jumlah yang cukup untuk membentuk suatu akumulasi minyak dan gas bumi[1]. Identifikasi batuan induk dapat dilakukan menggunakan data sampel batuan dari suatu formasi pada wilayah cekungan sedimen. Sebagai contoh di Cekungan Tarakan batuan induk yang teridentifikasi berupa batulanau di Formasi Meliat pada umur Miosen Tengah dan Formasi Tabul pada umur Miosen Akhir[3].

Penelitian ini bertujuan untuk mengetahui potensi pada batuan induk dengan menganalisis kandungan, tipe dan kematangan material organik. Salah satu metode yang dapat digunakan untuk mengetahui potensi batuan induk di suatu daerah adalah metode geokimia minyak dan gas bumi. Metode geokimia minyak dan gas bumi merupakan salah satu ilmu yang menerapkan prinsip-prinsip dasar kimia untuk mempelajari asal terbentuknya, migrasi, akumulasi, dan alterasi minyak bumi[1]. Metode geokimia minyak dan gas bumi telah dilakukan oleh beberapa penelitian, untuk menentukan kekayaan material organik, tipe kerogen dan kematangan serpih di area Abu Tartur[4]. Menentukan karakteristik batuan serpih sebagai potensi shale hydrocarbon[7] serta mengidentifikasi batuan induk karbonat dengan total organik rendah dan kematangan yang tinggi sebagai batuan induk efektif di China[2].

\section{Metodologi}

Penelitian ini dilakukan dengan menggunakan pembuktian secara akumulatif berdasarkan data bawah permukaan (data sumur) yang disediakan oleh PT. Pertamina EP. Metode penelitian yang dilakukan berdasarkan data analisis geokimia sampel batuan yang merupakan data hasil analisis screening yang sebelumnya telah dianalisis di laboratorium oleh perusahaan. Penelitian ini menggunakan data dari Formasi Santul yang terdapat pada lima sumur pengeboran, dengan sampel batuan berupa serbuk pengeboran (cuttings) dan side wall core (swc)(Gambar $\mathbf{1})$. 


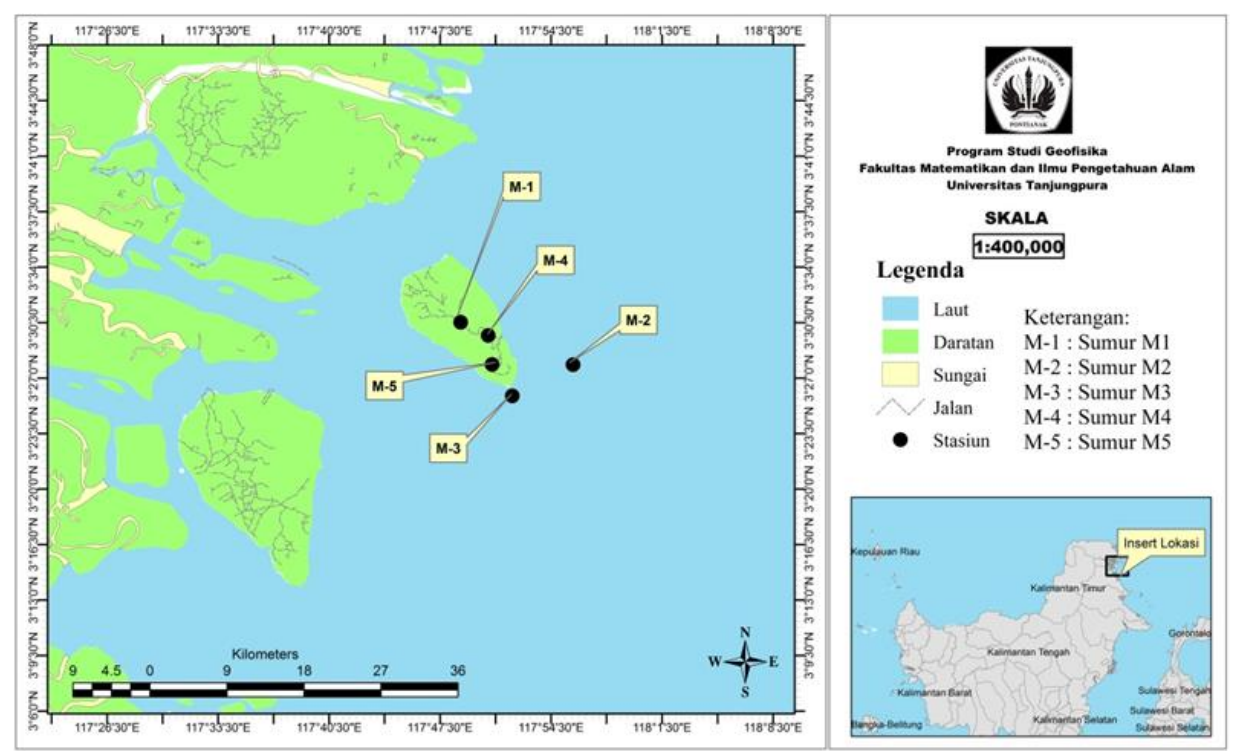

Gambar 1. Peta Lokasi Penelitian

Analisis geokimia yang dilakukan untuk mengetahui potensi pada batuan induk didasarkan pada analisis data Total Organic Carbon (TOC) untuk mengetahui kandungan material organik pada batuan induk. Analisis Rock Eval Pyrolysis (REP) untuk mengetahui tipe kerogen (material organik penyusun batuan induk), penentuan tipe kerogen berdasarkan parameter hasil analisis REP yaitu Tmax dan Hydrogen Index (HI). Analisis kematangan batuan induk menggunakan nilai reflektansi vitrinit (Ro\%). Pengambilan kesimpulan mengenai potensi batuan induk pada penelitian ini menga$\mathrm{cu}$ pada tabel potensi batuan induk[5] yang disajikan pada Tabel 1, Tabel 2, dan Tabel 3.

Tabel 1. Kuantitas dan Kualitas Material Organik Penyusun Batuan Induk

\begin{tabular}{ll}
\hline$\%$ TOC & Kualitas \\
\hline $0-0.5$ & Buruk \\
$0.5-1$ & Cukup \\
$1-2$ & Baik \\
$2-4$ & Sangat Baik \\
$>4$ & Istimewa \\
\hline
\end{tabular}

Tabel 2. Tipe kerogen dan kecenderungan jenis hidrokarbon yang dihasilkan

\begin{tabular}{lll}
\hline $\begin{array}{l}\text { Tipe } \\
\text { Kerogen }\end{array}$ & $\begin{array}{l}\text { Hidrogen } \\
\text { Indeks } \\
(\mathrm{mgHC} / \mathrm{g} \text { TOC })\end{array}$ & $\begin{array}{l}\text { Jenis } \\
\text { Hidrokarbon } \\
\text { yang dihasilkan }\end{array}$ \\
\hline I & $>600$ & Minyak \\
II & $300-600$ & $\begin{array}{l}\text { Minyak } \\
\text { Campuran } \\
\text { Minyak dan Gas }\end{array}$ \\
II/III & $200-300$ & Gas \\
& & Tidak ada \\
hidrokarbon
\end{tabular}

Tabel 3. Tingkat Kematangan Material Organik Penyusun Batuan Induk

\begin{tabular}{llll}
\hline \multicolumn{2}{l}{ Tingkat Kematangan } & $\mathrm{Ro}(\%)$ & $\mathrm{Tmax}\left({ }^{\circ} \mathrm{C}\right)$ \\
\hline Belum Matang & & $0.2-0.6$ & $<435$ \\
\hline \multirow{3}{*}{ Matang } & Awal & $0.6-0.65$ & $435-445$ \\
\cline { 2 - 4 } & Puncak & $0.65-0.9$ & $445-450$ \\
\cline { 2 - 4 } & Akhir & $0.9-1.35$ & $450-470$ \\
\hline Lewat Matang & & $>1.35$ & $>470$ \\
\hline
\end{tabular}

\section{Hasil dan Pembahasan}

Kandungan material organik dapat diidentifikasi menggunakan analisis kandungan TOC. Berdasarkan hasil analisis kandungan TOC batuan induk pada penelitian ini (Gambar 2) terdapat 66 sampel batuan yang memiliki kandungan material organik buruk hingga baik (poor-good) sebagai batuan induk yang memiliki nilai TOC $0.25 \%$ hingga $1.93 \%$ dan 25 sampel batuan yang memiliki kandungan material organik sangat baik hingga istimewa (very goodexcellent) sebagai batuan induk yang memiliki nilai TOC $2.44 \%$ hingga $10.81 \%$. Kandungan material organik berdasarkan nilai TOC tiap sumur pengeboran dapat terlihat pada Tabel 4.

Tabel 4. Kandungan Material Organik berdasarkan Nilai TOC

\begin{tabular}{lll}
\hline Sumur & Nilai TOC (\%) & Kualitas \\
\hline M-1 & $0.99-10.81$ & Cukup-Istimewa \\
M-2 & $0.25-3$ & Buruk-Sangat Baik \\
M-3 & $1.00-2.46$ & Baik-Sangat Baik \\
M-4 & $0.56-4.09$ & Baik-Istimewa \\
M-5 & $2.14-8.42$ & Sangat Baik-Istimewa \\
\hline
\end{tabular}




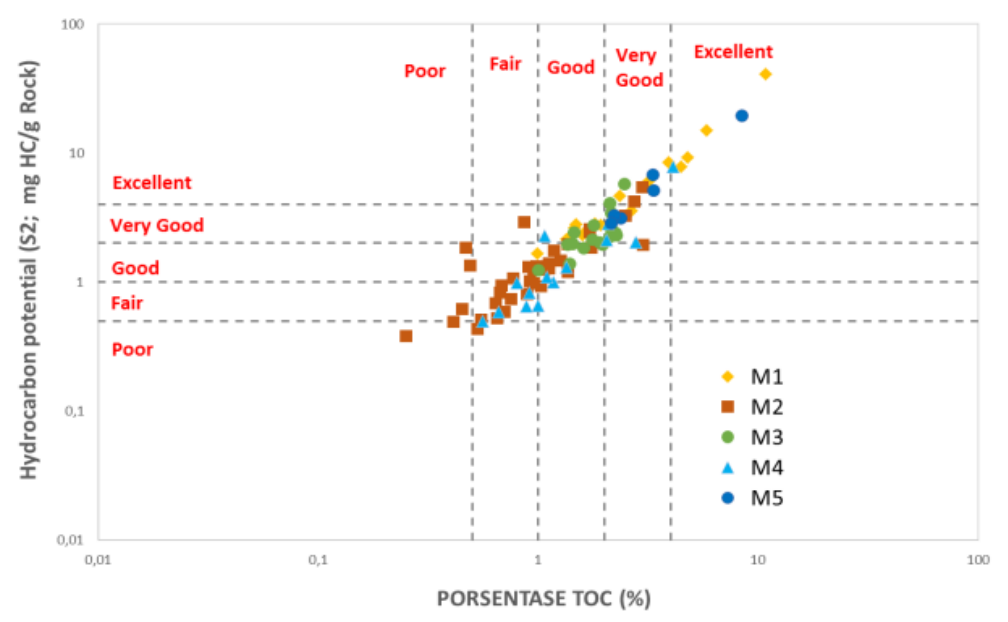

Gambar 2. Kuantitas dan Kualitas Material Organik Penyusun Batuan Induk

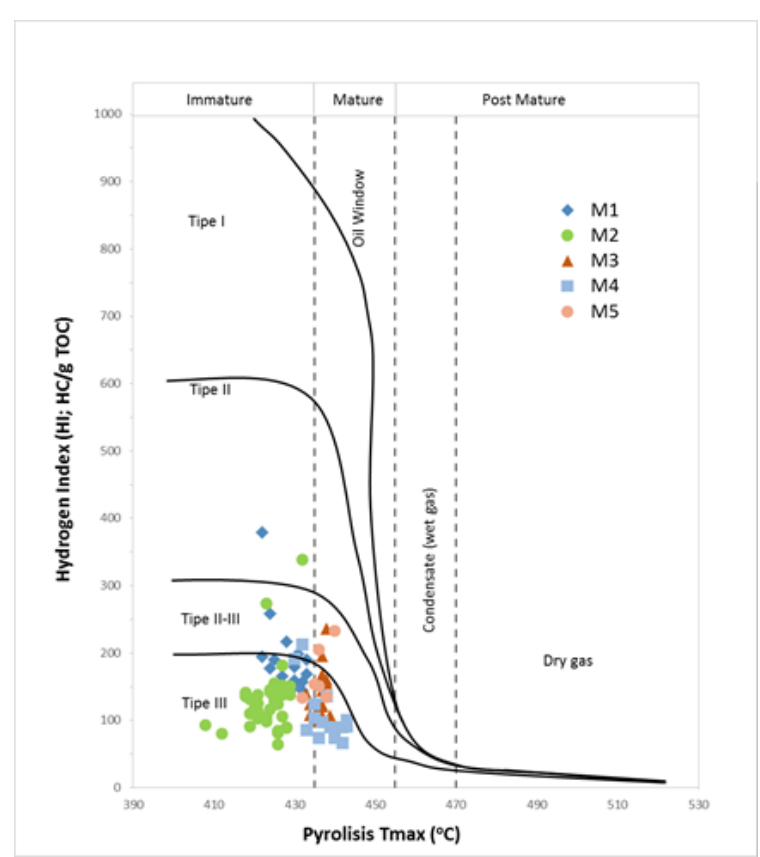

Gambar 3. Tipe Kerogen

Hasil analisis tipe kerogen menggunakan Tmax dan HI, terdapat 83 sampel batuan yang menunjukkan kerogen tipe III dimana kerogennya terdiri dari kelompok maseral Vitrinit, yang berasal dari material organik lingkungan daratan seperti material kayu atau selulosa tanaman dan cenderung akan menghasilkan hidrokarbon dalam bentuk gas. Terdapat 7 sampel batuan yang menunjukkan kerogen tipe II/III yang material organiknya berasal dari campuran lingkungan daratan dan lautan (marine) dan cenderung akan menghasilkan minyak dan gas. Terdapat 3 sampel batuan yang menunjukkan kerogen tipe II, dimana kerogen berasal dari material organik polen/spora, lapisan lilin tanaman, resin tanaman, alga laut, dan lemak tanaman dan cenderung akan menghasilkan hidrokarbon dalam bentuk minyak. Penelitian ini menunjukkan tipe kerogen dari lima sumur pengeboran memiliki tipe yang berbeda-beda (Gambar 3). Sumur M-1 dan M-2 memiliki kerogen tipe III, tipe II/III dan tipe II. Sedangkan pada sumur M-3, M-4 dan M-5 memiliki kerogen tipe III dan tipe II/III. Tipe kerogen berdasarkan nilai HI pada setiap sumur dapat dilihat pada Tabel 5.

Tabel 5. Tipe Kerogen berdasarkan nilai HI

\begin{tabular}{lll}
\hline Sumur & $\begin{array}{l}\text { Nilai HI } \\
\text { (mgHC/g TOC) }\end{array}$ & $\begin{array}{l}\text { Tipe Material } \\
\text { Organik }\end{array}$ \\
\hline M-1 & $133-379$ & II. II/III. III \\
M-2 & $64-394$ & II. II/III. III \\
M-3 & $101-236$ & II/III.III \\
M-4 & $66-213$ & II/III. III \\
M-5 & $133-233$ & II/III. III \\
\hline
\end{tabular}

Tingkat kematangan batuan induk dapat diketahui melalui kematangan material organik berdasarkan analisis reflektansi vitrinit (Ro\%) (Gambar 4). Hasil analisis kematangan material organik terdapat 59 sampel batuan yang berada pada tahap belum matang dengan nilai $<0.6$ Ro\% dan terdapat 7 sampel batuan yang berada pada tahap matang dengan nilai 0.6 hingga 0.71 Ro\%. Hasil ini menunjukkan bahwa kematangan material organik dimulai pada kedalaman $>2500$ meter di bawah permukaan bumi. Penelitian ini menunjukkan kematangan material organik dari lima sumur pengeboran memiliki tingkat kematangan yang berbeda-beda (Gambar 4). Sumur M-1, M-2, dan M-3 menunjukkan kematangan material organik adalah belum matang (immature) sedangkan pada sumur M-4 dan M-5 menunjukkan kematangan material organik belum matang (immature) dan matang (mature). Tingkat kematangan berdasarkan nilai Ro\% pada setiap sumur dapat dilihat pada Tabel 6. 


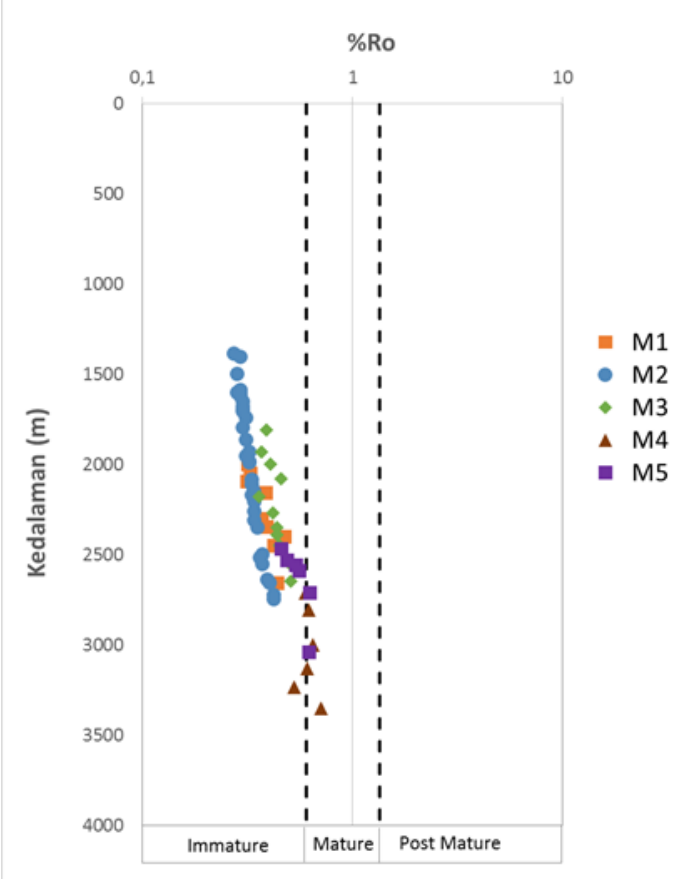

Gambar 4. Tingkat Kematangan Material Organik

Tabel 6. Tingkat Kematangan Material Organik berdasarkan nilai Ro\%

\begin{tabular}{|c|c|c|}
\hline Sumur & Nilai Ro\% & Kematangan \\
\hline M-1 & $0.32-0.38$ & Belum Matang \\
\hline M-2 & $0.27-0.42$ & Belum Matang \\
\hline$M-3$ & $0.36-0.51$ & $\begin{array}{l}\text { Belum matang. } \\
\text { Matang }\end{array}$ \\
\hline M-4 & $0.53-0.71$ & $\begin{array}{l}\text { Belum matang. } \\
\text { Matang }\end{array}$ \\
\hline M-5 & $0.46-0.63$ & $\begin{array}{l}\text { Belum matang. } \\
\text { Matang }\end{array}$ \\
\hline
\end{tabular}

\section{Kesimpulan}

Analisis kandungan material organik menunjukkan sebanyak 66 sampel batuan yang memiliki kandungan material organik buruk hingga baik (poor-good) sebagai batuan induk dengan nilai TOC $0.25 \%$ hingga $1.93 \%$ dan 25 sampel batuan yang memiliki kandungan material organik sangat baik hingga istimewa (very good-excellent) sebagai batuan induk dengan nilai TOC $2.44 \%$ hingga $10.81 \%$. Dari hasil ini, kandungan material organik yang baik sebagai batuan induk terdapat pada sumur M-1 dan M-5 yang memiliki kandungan cukup hingga istimewa (fair-excellent).

Analisis tipe material organik menunjukkan bahwa sebanyak 83 sampel batuan mengandung kerogen tipe III yang cenderung menghasilkan hidrokarbon dalam bentuk gas. Sebanyak 7 sampel batuan mengandung kerogen tipe II/III yang cenderung menghasilkan minyak dan gas dan 2 sampel batuan dari sumur M1 dan M2 mengandung kerogen tipe II yang cenderung menghasilkan minyak.

Analisis kematangan material organik menggunakan reflektansi vitrinit (Ro\%) menunjukkan sebanyak 59 sampel batuan yang berada pada tahap belum matang dengan nilai $<0.6$ Ro\% dan terdapat 7 sampel batuan yang berada pada tahap matang dengan nilai 0.6 hingga 0.71 Ro\%. Kematangan material organik dimulai pada kedalaman $>2500$ meter di bawah permukaan bumi. Dari hasil ini sumur yang telah memasuki tahap matang berada pada sumur $\mathrm{M}$ 4 dan M-5.

\section{Pengakuan}

Penulis menyampaikan ucapan terima kasih kepada PT. PERTAMINA EP yang telah menyediakan data untuk keperluan penelitian.

\section{Daftar Pustaka}

[1] Hunt. J.M., Petroleum Geochemistry and Geology,2nd Edition, W.H. Freeman and Company, New York, pp 743.1996.

[2] Huo. Z., Pang. X., Chen. J., Zhang. J., Song. M., Guo. K., Li. P., Li. W., dan Liang. Y., Carbonate source rock with low total organic carbon content and high maturity as effective source rock in China: A review, Journal of Asian Earth Science, 176, 8-26, 2019.

[3] Larasati. D., Suprayogi. K., dan Akbar. A., Cruide Oil Characterization of Tarakan Basin: Aplication of Biomarkers, The 9th International Conference on Petroleum Geochemistry in the Africa-Asia Region, 2016.

[4] Nady. Mohamed M. El, dan Hammad. Mahmoud M., Organic richness, kerogen types and maturity in the shales of the Dakhla and Duwi formations in Abu Tartur area. Western Desert, Egypt: Implication of Rock-Eval Pyrolysis, Egyptian Journal of Petroleum, 24, 423-428, 2015.

[5] Pertamina BPPKA, Petroleum Geology of Indonesian Basins (Prinsiples, Methods and Application) Volume 5 Tarakan Basin Northeast Kalimantan ; Jakarta, 2005.

[6] Peters. K.E. dan Cassa. M. R., Applied Source Rock Geochemistry, AAPG Memoir 60 Chapter 5: Tulsa. Oklahoma USA, 93-120, 1994.

[7] Sumortato. T. A., Haris. A., Bachtiar. A., dan Usman. A., Karakteristik batuan serpih pada lapangan "RK" formasi tanjung. cekungan barito. kalimantan selatan sebagai potensi shale hydrocarbon, Spektra: Jurnal Fisika dan Aplikasinya, 2(1), 37-44, 2017. 